\title{
KARST SURFACE FEATURES OF THE HARD LAMINATED CRUST (CALICHE HARDPAN) IN THE MERSIN AREA, SOUTHERN TURKEY
}

\author{
KRAŠKE POVRŠINSKE OBLIKE TRDIH LAMINIRANIH SKORIJ \\ (KALKRET) NA OBMOČJU PROVINCE MERSIN V JUŽNI TURČIJI
}

\author{
Mushin EREN $^{1}$ \& Zubeyde HATIPOGLU-BAGCI ${ }^{1}$
}

\begin{abstract}
s
UDC 551.435.8(560)

Mushin Eren \& Zubeyde Hatipoglu-Bagci: Karst surface features of the hard laminated crust (caliche hardpan) in the Mersin area, southern Turkey

The study area is located in the Mersin province where caliches are widespread and occur in a variety of forms such as powdery, nodular, tubular, fracture-infill, laminar crust, hard laminated crust (caliche hardpan), pisolithic crust. The hard laminated crust shows distinctive karst surface features of karren. These include kamenitza, rillenkarren, solution pit and solution enlarged fracture (kluftkarren). First two karst features are common and closely associated with dome- and ridge-like morphologies termed caliche tepees or pseudo-anticlines. Kamenitzas or solution basins are dish-shaped depressions with flat bottom and sharp and overhanging sides which resulted from ponding water mostly at the top of caliche tepees. Rillenkarren are solutional flutes separated by sharp angular ridges, with length of less than $15 \mathrm{~cm}$. They are well developed on the inclined surfaces of surface irregularities at or near the top of caliche tepees and form from sheet flow. Solution pits are narrow, cylindrical shaped karst troughs formed by stemflow drainage beneath trees. The kluftkarrens are products of dissolution by channelised surface water flowing along a fracture. The coexistence of caliche and karst features is important to indicate a climatic change from semiarid to humid conditions.

Keywords: karstification, karren, caliche, hard laminated crust (hardpan), Quaternary, Turkey.
\end{abstract}

Izvleček

UDK 551.435.8(560)

Mushin Eren \& Zubeyde Hatipoglu-Bagci: Kraške površinske oblike trdih laminiranih skorij (kalkret) na območju province Mersin v južni Turčiji

$\mathrm{V}$ članku obravnavamo kalkrete $\mathrm{v}$ provinci Mersin v južni Turčiji, ki so tam razširjene v številnih pojavnih oblikah. Na kalkretah se pojavljajo različne skalne oblike, kot so škavnice, dežni žlebiči, korozijske vdolbinice in korozijsko razširjene razpoke. Škavnice in dežni žlebiči so povezani z tipično morfologijo »kupol in grebenov«, imenovani kalkretni tepiji (angl. tepee structure) ali psevdo antiklinale. Škavnice so korozijske oblike skledastih oblik z ravnim dnom in ostrimi previsnimi robovi, ki so nastale $\mathrm{z}$ zastajanjem vode na vrhu kalkretnih tepijev. Dežni žlebiči so korozijski žlebovi ločeni z ostrimi grebeni, dolžine do $15 \mathrm{~cm}$. Nastali so z raztapljanjem vodnega filma na nagnjenih površinah, večino blizu vrha kalkretnih tepijev. Korozijske vdolbinice so ozke cilindrični skalne oblike, nastale s korozijo raztopin iz drevesnih debel. Poklinaste škraplje (kluftkarren) so nastale $\mathrm{z}$ raztapljanjem vode, ki teče vzdolž razpok. Soobstoj kalkretov in kraških oblik je zanimiv pojav, ki kaže na prehajanje suhe klime v manj suho in vlažno klimo.

Ključne besede: zakrasevanje, škraplje, kalkreti, trde laminirane skorje, kvartar, Turčija.

\footnotetext{
${ }^{1}$ Mersin Üniversitesi, Mühendislik Fakültesi, Jeoloji Mühendisliği Bölümü, TR-33343 Çiftlikköy, Mersin, Turkey, e-mails: m_eren@yahoo.com, zubeyde@mersin.edu.tr
}

Received/Prejeto: 3.9.2009 


\section{INTRODUCTION}

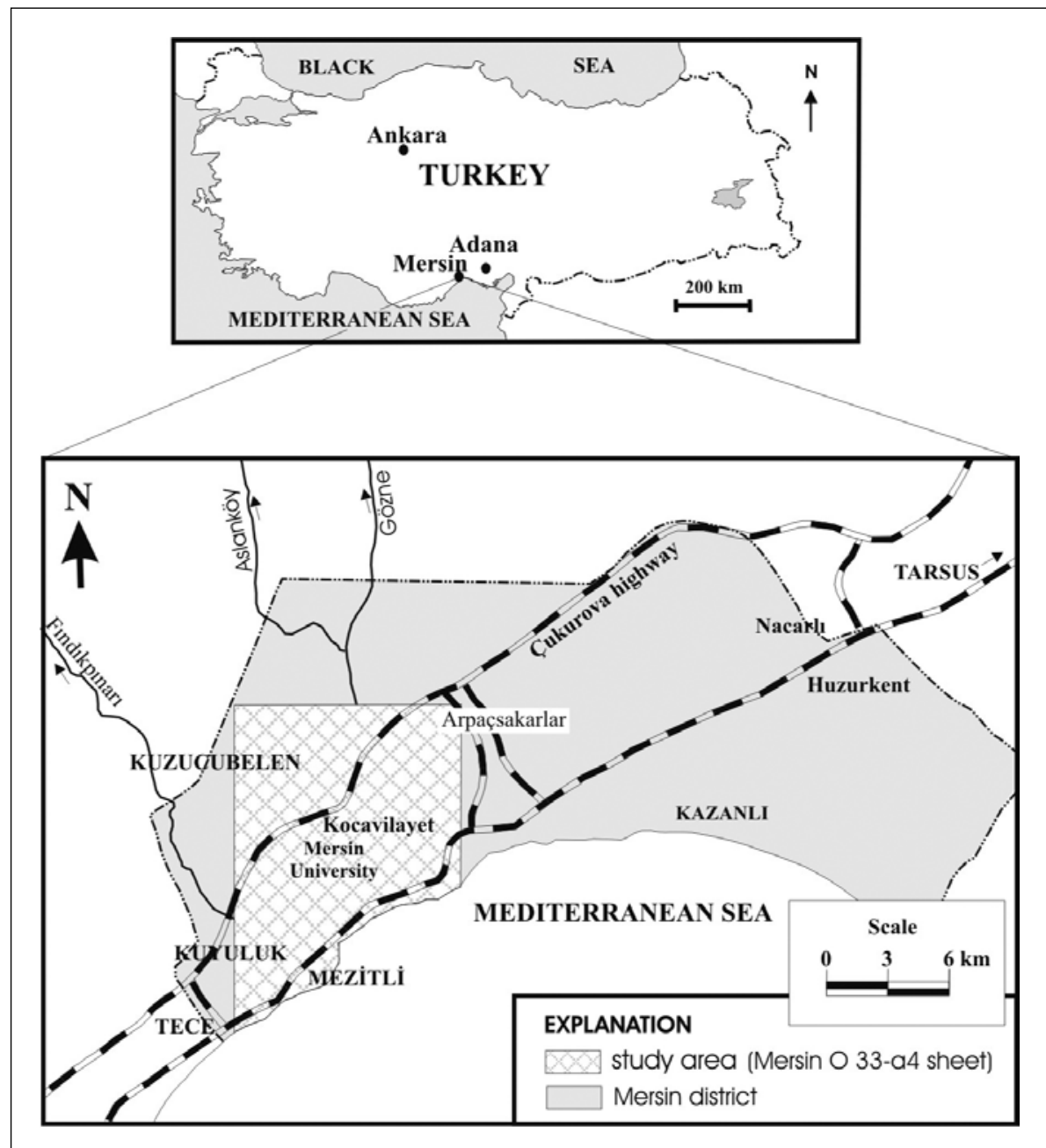

Fig. 1: Location map of the study area.

The study area is located in Mersin (Fig. 1) which is a city near the Mediterranean Sea. In the Mersin area, caliches are widespread and occur in a variety of forms from powdery to nodular to highly indurated crusts (Eren et al. 2004, 2008). The hard laminated crust (caliche hardpan) shows distinctive karst surface features of karren, including rillenkarren, kamenitza, solutional pit, and solution enlarged fracture (kluftkarren) which are the subject of this paper.

There is a large number of publications on general karst (e.g., Sweeting 1973; Bögli 1980; Esteban \& Klappa 1983; James \& Choquette 1984; Ford \& Williams 1989), palaeokarst (e.g., Walkden 1974; Wright 1982; Vanstone 1998; Molina et al. 1999; Miller \& Mitchell 2003; Yılmaz \& Altıner 2006; Evans \& Reed 2007) and related subjects (e.g., Wray 1997; Crowther 1998; Fiol et al. 1996; Di Stefano \& Mindszenty 2000; Doğan \& Özel 2005; Lepirica 2008; Lipar 2009). But there is little information available concerning karstification in caliches (Vanstone 1996). Karst or palaeokarst studies related to Turkey are also very limited such as Öztaş (1992), Doğan \& Özel (2005), Yllmaz \& Altıner (2006).

\section{TERMINOLOGY AND METHODOLOGY}

Caliche, synonymous with calcrete (Siesser 1973), is a near surface, terrestrial accumulation of predominantly calcium carbonate $\left(\mathrm{CaCO}_{3}\right)$, which occurs in a variety of forms on and/or within the sedimentary rocks, sediments and soils (Wright \& Tucker 1991; Goudie 1973; Watts 1980). Caliche forms as a result of soil-forming process (pedogenic caliche; Watts 1980; Aristarain 1970) or ground-water evaporation (ground-water caliche; Goudie 1973).

Hard laminated crust (caliche hardpan), syn. petrocalcic horizon, is an indurated horizon, sheet-like with sharp upper surface and gradational lower surface, and illustrating typically a complex internal fabric (Wright \& Tucker 1991). 


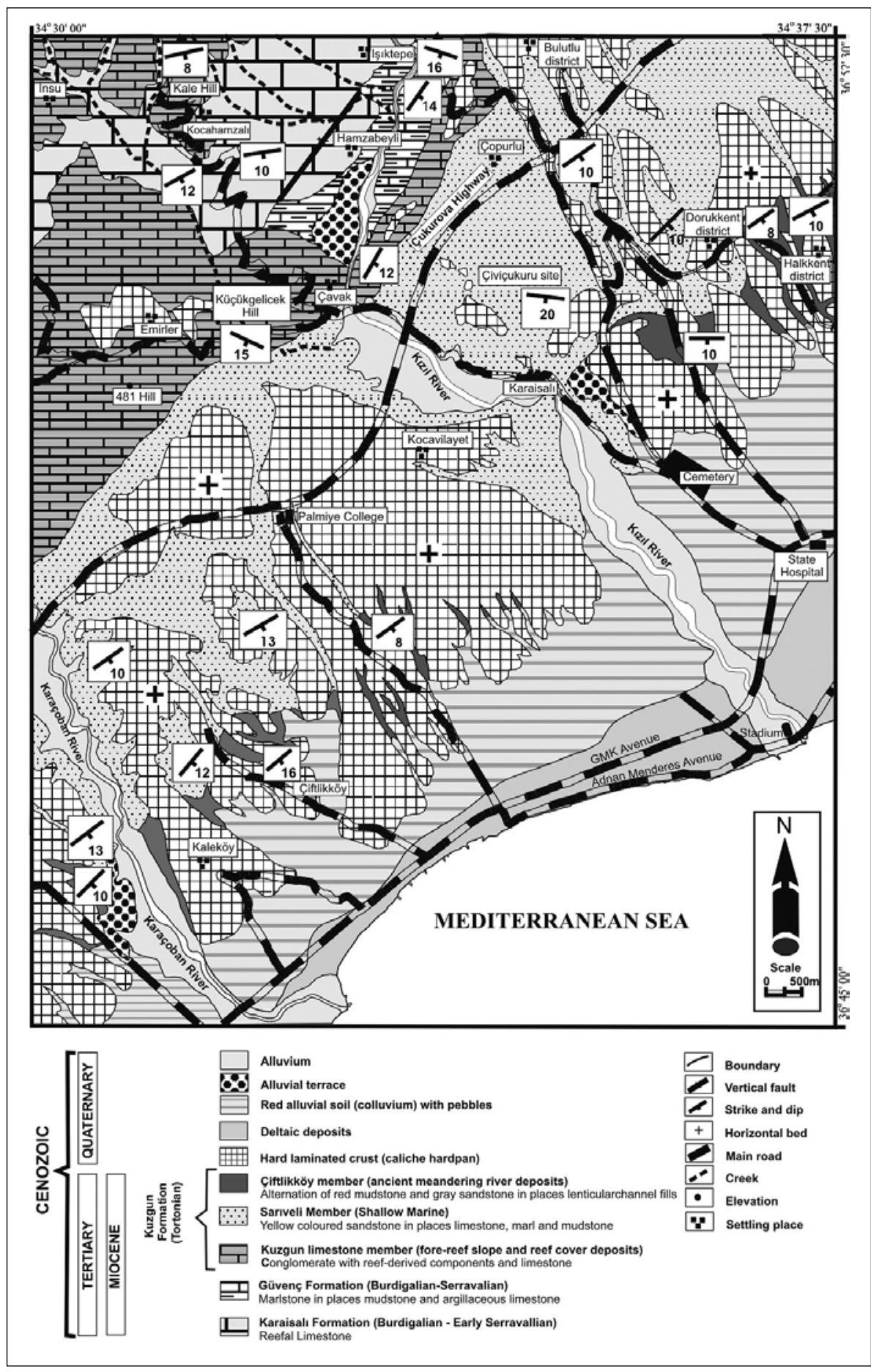

Fig. 2: Geological map of the study area.

The term "tepee" was introduced by Adams \& Frenzel (1950) describing antiformal sedimentary structures in the carbonates (Assereto \& Kendal 1977; Watts 1977).

The term "pseudo-anticline" describes any antiform structure formed by the expansion of indurated carbonate beds where the process and environment responsible for expansion can not be established (Assereto \& Kendall 1977).

Karren (syn. lapies) is a general term used to describe minor forms of karst with dimensions of less than $10 \mathrm{~m}$, that are due to solution of rock on its surface (Sweeting 1973; Bögli 1980; James \& Choquette 1984; Ford \& Williams 1989). Karren forms include sharp-rigded grooves (rillenkarren), solutional hollows (kamenitzas), solutional pits, solution enlarged joints (kluftkarren), and the others (see Sweeting 1973; Ford \& Williams 1989).

This study is mainly based on field observations. During the field work, an area of approximately $140 \mathrm{~km}^{2}$ of the Mersin O 33-a4 sheet was mapped on a scale of 1: 25000 (Fig. 2). Small-scale karst features were described, and their size was measured. Fourty samples were collected from caliche hardpan, then thinsections were prepared and examined under an optical microscope. XRD analyses were performed on the all samples at the laboratory of the General Directorate of Mineral Research and Exploration (MTA), Ankara, Turkey. ICP-AES analyses were carried out at the ACME Analytical Laboratories LTD., Vancouver, BC Canada to illustrate chemical composition of selected samples. 


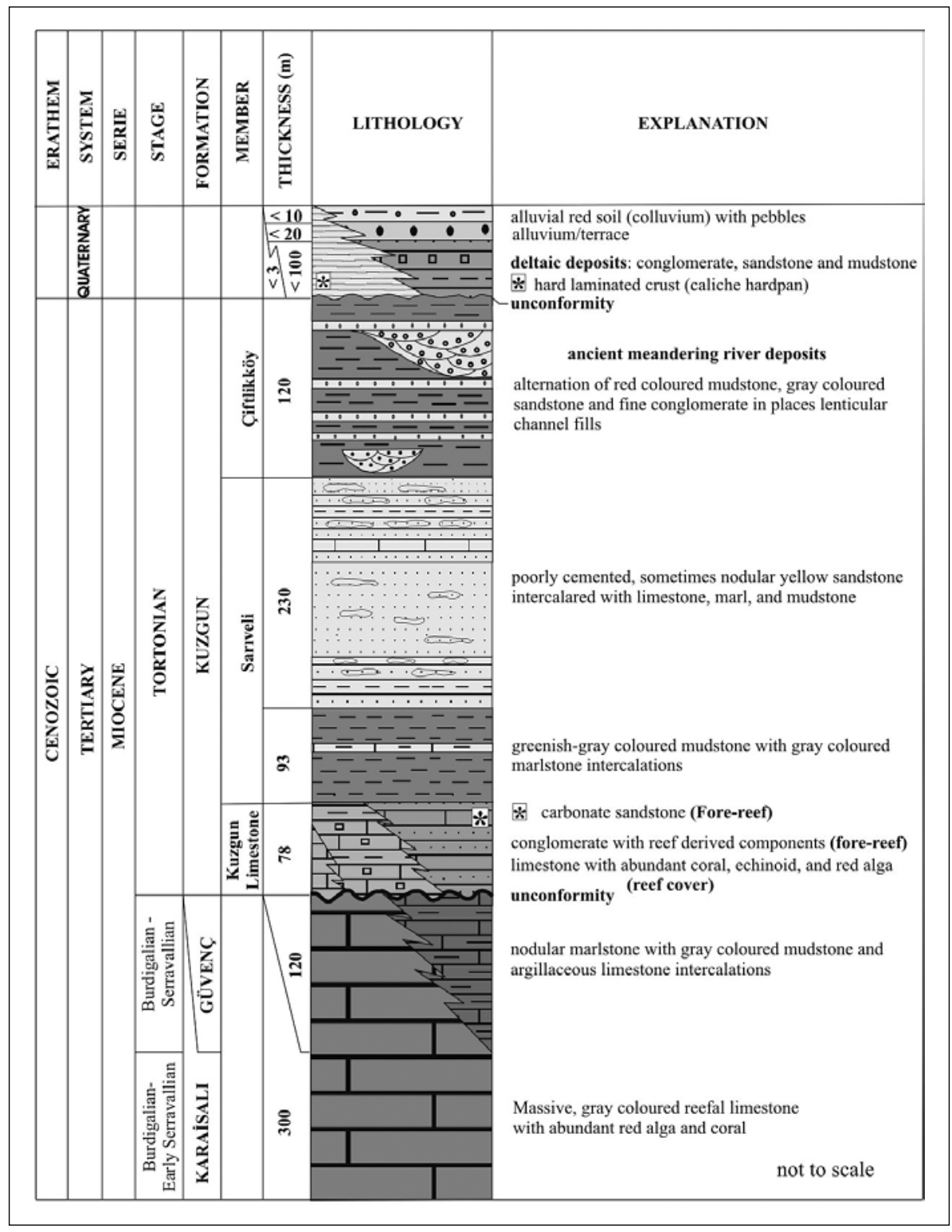

Fig. 3: Generalized stratigraphic columnar section of the study area.

\section{GEOLOGICAL SETTING}

The study area is located on the western flank of the Adana Basin where Tertiary and Quaternary units are present (Figs. $2 \& 3$ ). The Tertiary units are represented by the Karaisalı Formation (Burdigalian-Early Serravalian), Güvenç Formation (Burdigalian-Serravalian), and Kuzgun Formation (Tortonian). The Karaisalı Formation is composed of grey coloured reefal limestone with abundant red algae and corals deposited on the topographic highs in a shallow marine environment. The Güvenç Formation starts with a grey to greenish-grey coloured mudstone-argillaceous limestone alternation at the bottom, and then continues with predominantly grey coloured marlstone with mudstone intervals. The formation contains various microfossils such as Planorbulina sp., Quinqueloculina sp., Textularia sp., Amphistegina sp., Globigerina sp., and Globigerinatheka sp. The benthic forms disappear upwards in the formation in contrast to planktic forms. The fossil content of the formation indicates deposition in a relatively deep marine environment among the topographic highs. Therefore, the Karaisalı 
Formation represents a vertical and horizontal transition to the Güvenç Formation. The Kuzgun Formation is subdivided into three members: the Kuzgun limestone, Sarıveli and Çiftlikköy members. The Kuzgun limestone member contains fore-reef slope deposits and reef cover sediments. The Sariveli member consists of green coloured mudstone at the bottom then predominantly yellow coloured sandstone with yellow coloured mudstone intervals bearing marine fossils. The Çiftlikköy member is represented by ancient meandering river deposits, in which red coloured sediments are dominant. The Quaternary units are made up of the hard laminated crust (caliche hardpan), deltaic deposits, pebbly alluvial red soils (colluvium) and recent alluvium/terrace sediments.

Eren et al. $(2004,2008)$ provide detailed information on caliches in the Mersin area where they are widespread and form in a variety of forms such as powdery, nodular, tubular, fracture-infill, laminar crust, hard laminated crust (hardpan), pisolithic crust. The hard laminated crust (caliche hardpan) occupies large areas (Fig. 2) and appears as wavy crust on the small ridges and highs, forming a terrace-like morphology at topographic levels of 20 to $250 \mathrm{~m}$ asl. The caliche hardpan covers the lithologically different beds of the Kuzgun Formation (Fig. 2) and also remains of alluvial materials in erosional troughs. It is typically composed of a cream

Tab. 1: Semi-quantitative estimations of minerals in the hard laminated crust by X-ray diffraction.

\begin{tabular}{|c|c|c|c|c|c|c|c|}
\hline sample no & calcite & dolomite & quartz & feldspar & illite & palygorskite & smectite \\
\hline $\mathrm{H}-1$ & +++ & + & ac & & & & + \\
\hline $\mathrm{H}-2$ & +++ & & + & & & & + \\
\hline $\mathrm{H}-3$ & +++ & & + & & & ac & + \\
\hline $\mathrm{H}-4$ & ++++ & & ac & & & & + \\
\hline $\mathrm{H}-4 \mathrm{a}$ & ++++ & & + & + & & & \\
\hline $\mathrm{H}-5$ & +++++ & ac & ac & & & & \\
\hline H-6 & ++++ & & + & & & & + \\
\hline $\mathrm{H}-8$ & +++++ & & ac & & & & \\
\hline $\mathrm{H}-9$ & ++++ & & ac & & & ac & + \\
\hline HP-1 & +++ & & + & + & & & + \\
\hline HP-2 & +++ & & + & & & & + \\
\hline HP-3 & +++ & & + & ac & & & + \\
\hline HP-4 & +++ & & + & + & & & + \\
\hline HP-5 & +++ & & + & + & $\mathrm{ac}$ & & + \\
\hline HP-6 & +++ & & + & + & & ac & + \\
\hline HP-7 & ++++ & & + & & & & ac \\
\hline HP-8 & ++++ & & + & & & ac & \\
\hline HP-9 & +++ & & + & & & ac & + \\
\hline HP-11 & +++ & & + & + & & & + \\
\hline HP-12 & +++ & & + & ac & & & + \\
\hline HP-13 & ++++ & & + & & & & ac \\
\hline
\end{tabular}

$+:$ relative abundance of minerals; ac : accessory coloured, evenly discontinuously laminated, indurated, wavy horizon of calcium carbonate with an average thickness of 1 to $1.5 \mathrm{~m}$. The carbonate crust displays a sharp upper surface and a gradual lower surface, passing into nodular to tubular caliche horizons. The upper surface commonly shows dome- and ridge-like morphologies termed caliche tepees (Kendall \& Warren 1987) or pseudo-anticlines (Price 1925; Jenning \& Sweeting 1961; Aristarain 1970; Watts 1977) with wider troughs between them. These antiform structures are described in more detail in Eren (2007). Small-scale karst surface features are moderately common on the caliche crust. The $\mathrm{XRD}$ analysis indicates that the caliche crust is mainly composed of calcite associated with minor smectite and palygorskite, and accessory quartz, feldspar, illite and dolomite (Tab. 1).

Palygorskite has an authigenic origin and associated with calcite as a minor constituent of the caliche samples (Kadir \& Eren 2008). Smectite and the accessory minerals are remains of the host-rocks and sediments (Eren et al. 2004, 2008). The ICP-AES analysis confirms the XRD results with high $\mathrm{CaCO}_{3}$ contents (avg. 90.98 wt\%) and small amounts of $\mathrm{SiO}_{2}$ (avg. 5.59 wt\%) and $\mathrm{Al}_{2} \mathrm{O}_{3}$ (avg. 0.63 wt\%; Tab. 2). Trace elements ( $\mathrm{Ba}, \mathrm{Cu}, \mathrm{Zn}, \mathrm{Ni}$, $\mathrm{Co}, \mathrm{Zr}, \mathrm{Ce}, \mathrm{Y}, \mathrm{Nb}, \mathrm{Sc}$ ) concentrations in the caliches have been inherited from the host-rocks and sediments with varying depletion which is due to their removal by infiltrating water (Eren et al. 2004, 2008). But Sr values of caliche hardpan samples are similar to those of host-rocks and sediments. Petrographic studies reveal that the hard laminated crust consists predominantly of micrite and microsparite, and exhibits typical and diagnostic caliche features such as wavy lamination, floating grains, circum-granular cracks, clotted texture, rhizoliths, alveolar texture, calcite needles, calcified filaments, spherulite-like Microcodium particules, and vadose caliche pisoliths. 
Tab. 2: Chemical composition of the hard laminated crust (caliche hardpan).

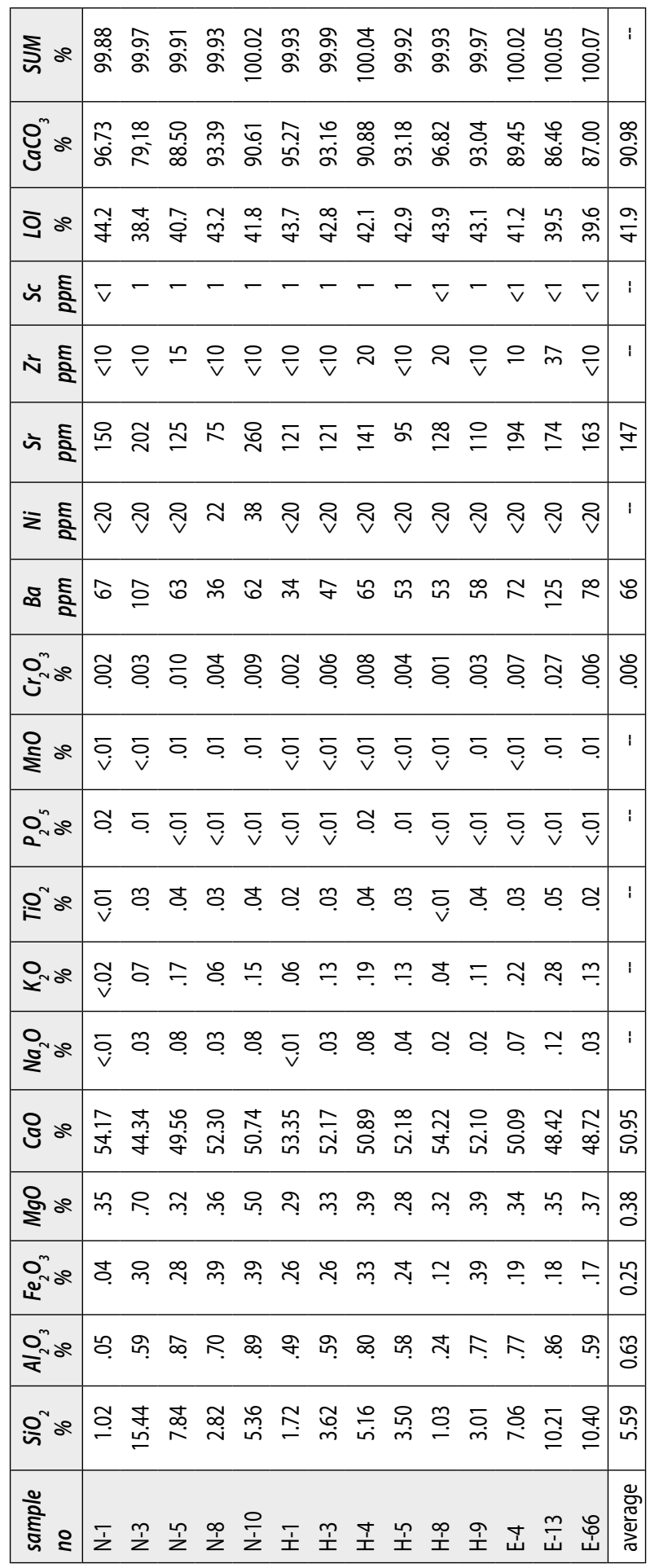

In the samples, $\mathrm{Cu}, \mathrm{Zn}, \mathrm{Co}, \mathrm{Ce}, \mathrm{Ta}, \mathrm{Y}$ and $\mathrm{Nb}$ concentrations are below the detection limits: 10 ppm for $\mathrm{Y}$ and $\mathrm{Nb}$, and 20 ppm for the others.

The calculation of $\mathrm{CaCO}_{3}$ contents is based on $\mathrm{CaO}$ concentrations.

\section{KARST FEATURES}

In the Mersin area, small-scale solutional karst features are moderately well developed on the hard laminated crust (caliche crust). These include different karren forms such as kamenitzas, rillenkarren, solution pits, and fracture-related karst forms (Fig. 4).

Kamenitzas (solution basins or pans, rock pools): These are the most common karst features on the caliche hardpan associated with dome- or ridge-like surface morphologies. The solution basins usually develop at the top of caliche tepees, and also on their slope irregularities, where it is more or less horizontal. Kamenitzas are generally rounded or elliptical, and also triangular or composite in shapes. They have variable sizes with a nearly flat bottom and sharp, steep or overhanging sides (Fig. $4 \mathrm{c}, \mathrm{d}$, e \& $\mathrm{f}$ ). Their size ranges from several centimetres up to $1.7 \mathrm{~m}$ across; their depth is usually $6-10 \mathrm{~cm}$, but $30 \mathrm{~cm}$ deep examples have also been found. Some of them show overflow channels.

Rillenkarren: This is one of the master karren types on the hard laminated crust. These are solutional flutes (Fig. $4 \mathrm{f} \mathrm{\&} \mathrm{g)} \mathrm{consisting} \mathrm{of} \mathrm{parallel} \mathrm{or} \mathrm{roughly} \mathrm{parallel}$ and subvertical grooves separated by sharp angular ridges (Sweeting 1973; Bögli 1980; Ford \& Williams 1989). They are particularly well developed on slopes of small reliefs at or near the top of dome- or ridge-like morphologies (caliche tepees or pseudo-anticlines), and often associated with small-sized kamenitzas. When they associate with kamenitzas, they extent downward from kaminitza on the slopes. Rillenkarrens are 1-2 cm wide, $1 \mathrm{~cm}$ or less deep, and 10-15 cm long.

Solutional pits: These are scarse karren types in the Mersin area, and differ from solutional pans (kamenitzas) in having a smaller diameter and a deeper depth. Solutional pits are cylindrical in shape with a diameter of $27-28 \mathrm{~cm}$ and a depth of approximately $12 \mathrm{~cm}$ (Fig. $4 \mathrm{~h}$ ). They have vertical and smooth walls and rounded bottoms.

Solution enlarged fractures (kluftkarren or grikes): This is the least common karren types in the Mersin area resulting from solution along joints (Fig. $4 \mathrm{c}$ ). These are approximately $11 \mathrm{~cm}$ wide, $15 \mathrm{~cm}$ deep, and several metres long. 

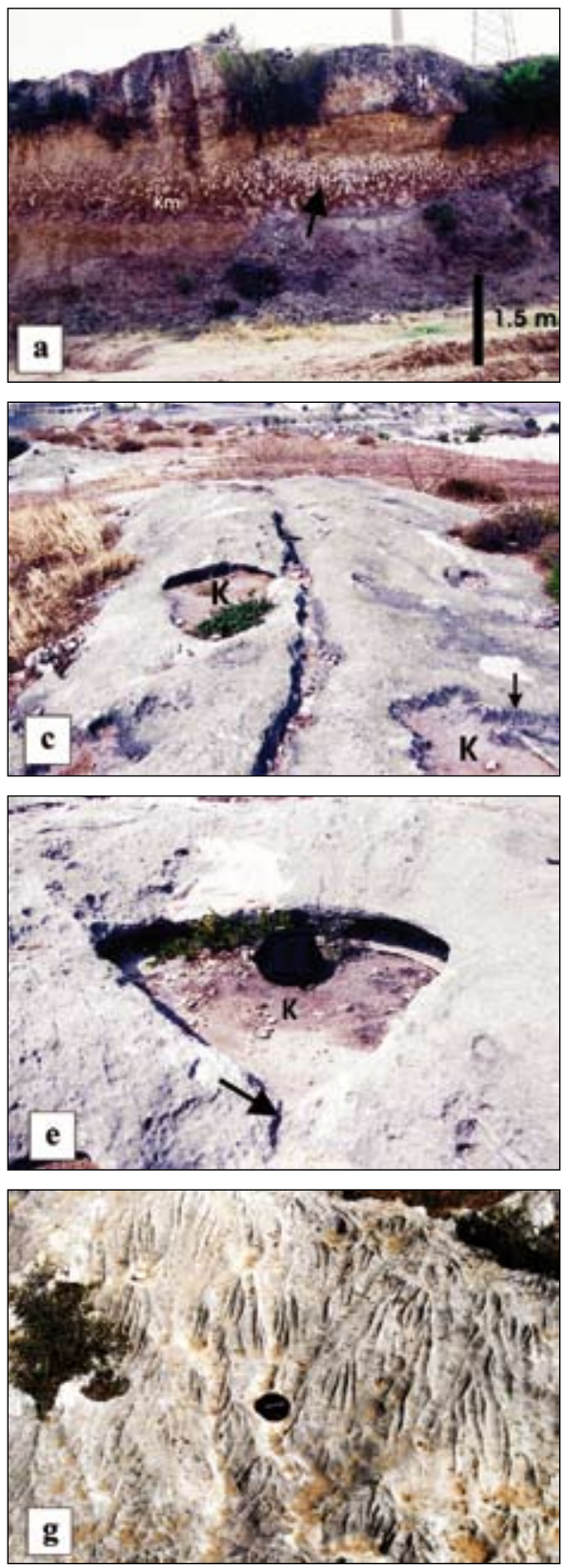
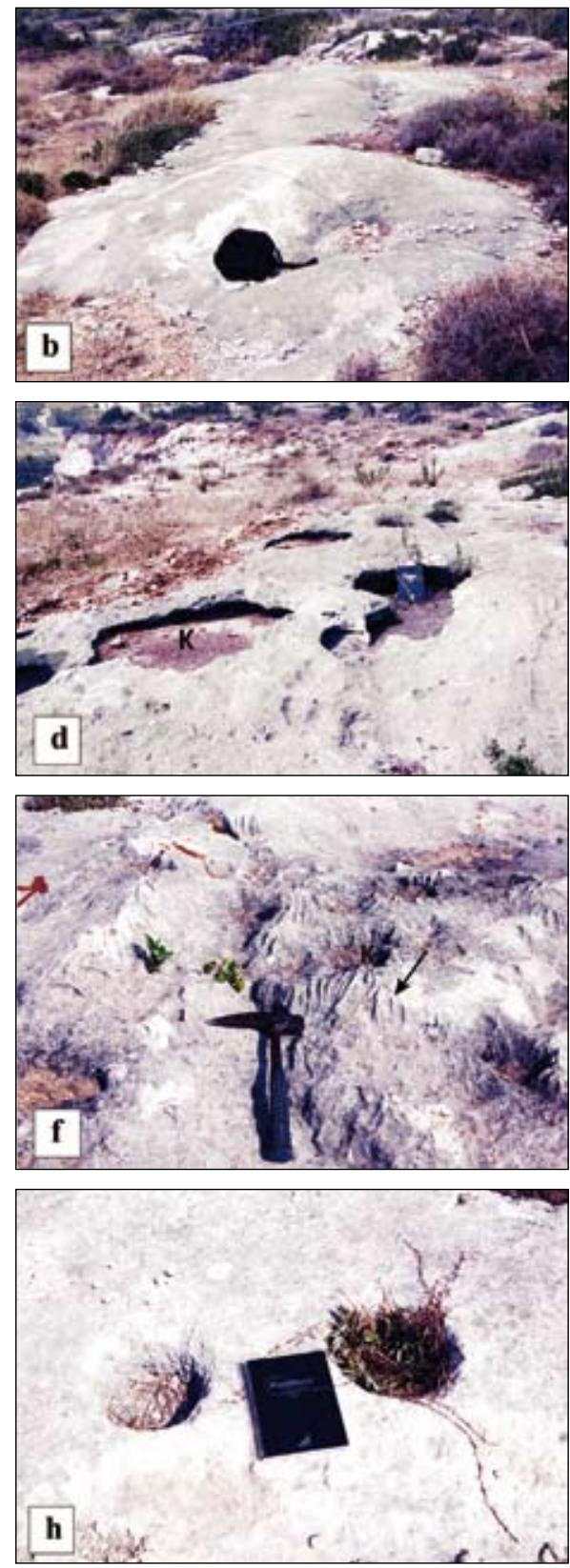

Fig. 4: Hard laminated crust (caliche hardpan) and its karst surface features.

a) Hard laminated caliche crust $(H)$ grading into nodular horizon (arrow) within the reddish-brown coloured mudstone (Km; overbank deposits) of the Kuzgun Formation in Tortonian age (Photo: M. Eren).

b) Dome-like surface morphology of the hard laminated crust (Photo: M. Eren).

c) Ridge-like surface morphology of the hard laminated crust showing solution pans (kamenitza: K) with overflowing channel (arrow) and solution enlarged fracture (kluftkarren indicated by an hammer; Photo: M. Eren).

d) Solution pans (kamenitza: $K$ ) with different shapes at the top of ridge-like surface morphology (Photo: Z. Hatipoglu-Bagcl).

e) Kamenitza with a triangular shape and a drainway (arrow; Photo: M. Eren).

f) Rillenkarren (arrow) associated with small sized kamenitzas (K) at the top of dome-like morphology (Photo: M. Eren).

g) Rillenkarren developed on the slope of low small reliefs at the top of dome-like morphology (Photo: M. Eren).

h) Solutional pits in cylindrical shape including soil and vegetation (Photo: Z. Hatipoglu-Bagci)

\section{INTERPRETATION}

Karst and caliche are basically two end-member products of subaerial weathering. Karstification describes the processes by which certain types of rocks are dissolved (e.g., Sweeting 1973). Whereas, caliche is a near surface, terrestrial accumulation of predominantly calcium carbonate $\left(\mathrm{CaCO}_{3}\right)$ in/or on preexisting rocks and sediments (Goudie 1973; Wright \& Tucker 1991; Watts
1980). Dissolution and precipitation of calcium carbonate are expressed by the following reaction:

$$
\mathrm{CaCO}_{3}+\mathrm{H}_{2} \mathrm{O}+\mathrm{CO} 2 \leftrightarrow \mathrm{Ca}_{2}++2 \mathrm{HCO}_{3}^{-}
$$

where carbon dioxide $\left(\mathrm{CO}_{2}\right)$ plays the major role controlling carbonate dissolution and precipitation. The 
solution capability of the water with respect to carbonate rocks is related directly to its carbon dioxide content. Rainwater contains only small amount of carbon dioxide in equilibrium with atmospheric $\mathrm{CO}_{2}$, so it is an extremely weak acid. In comparison with rainwater, soil water contains soil-derived carbon dioxide at far higher concentrations because of biological processes and is therefore much more corrosive.

Rainwater collecting in surface pools and basins is much more corrosive than the flowing sheet, because stagnant water accumulates additional carbon dioxide from decaying moss, algae, and other plant debris that grow in the wet spots of the bedrocks (White 1988). This is therefore a self enhancing process by which the deeper and larger pools become, the more vegetation can sustain the more soil that can be accumulated and the more plant debris are washed into them. Rillenkarren are solutional grooves resulted directly from rainwater running down on slopes of surface irregularities at the top of dome-like or ridge-like morphologies. Their development is apparently associated with the incipient stages of sheet flow, where the water films are thin and of smaller velocity than relatively thick sheet flow. It is widely accepted that dissolution is only process, by which rillenkarren develop. However, Fiol et al. (1996) emphasize a significant role of algae in the weathering process on limestone by weakening the structure of the surface, thereby allowing raindrop impact to dislodge fine rock particles. The close association of rillenkarren with the outer slopes of kamenitzas suggest that some rillenkarren are due to dissolution caused by overflowing rainwater from solution basins. The kluftkarren (grikes) are products of dissolution by channelised surface water flowing along a tensional fracture. Solution pits form in low areas among the dome- and ridge-like morphologies. They are considered to have formed by the concentration of acidified waters by stemflow drainage beneath trees (Vanstone 1998).

\section{CONCLUSIONS}

In our knowledge, this study documents for the first time small scale karst surface features (karren) associated with caliche. In the Mersin area, the hard laminated crust (caliche hardpan) exhibits moderately well developed karren. These include kamenitzas, rillenkarren, solution pits and kluftkarren (grikes) which are closely associated with dome- or ridge-like surface morphologies (Eren 2007), and formed by dissolution from ponding water, sheetflow, stemflow, and channelised flow of surface water along a fracture, respectively.

The climate in the region is semiarid which is favourable for caliche formation in contrast to karstifica- tion which requires more humid climatic conditions (Wright 1988; Ford \& Williams 1989; Vanstone 1996). The formation of caliche requires a favourable moisture balance and a source of calcium carbonate (Harrison 1977). Brief rainfall followed by a long period of rapid evaporation and dryness results precipitation of calcite. Whereas too much moisture during the wet period causes karstification (dissolution) of carbonate rocks. Therefore, karstification of caliche hardpan surface indicates a climatic change from a drier phase of climate to a wetter phase.

\section{ACKNOWLEDGEMENTS}

This paper forms a small part of a project which was financially supported by the Scientific and Technical Research Council of Turkey (TUBITAK) under the project no of YDABAG-102Y036. Therefore, the authors express their appreciation to TUBITAK. Appreciation is extended to Stephan Kempe for his careful review and constructive comments. 


\section{REFERENCES}

Adams, J.E. \& H.N. Frenzel, 1950: Capitan barrier reef, Texas and New Mexico.- Journal of Geology, 58, 289-312.

Aristarain, L.F., 1970: Chemical analyses of caliche profiles from the high plains, New Mexico.- Journal of Geology, 78, 201-212.

Assereto, R.L. \& C.G.St.C. Kendall, 1977: Nature, origin and classification of peritidal tepee structures and related breccias.- Sedimentology, 24, 153-210.

Bögli, J., 1980: Karst hydrology and physical speleology.Springer-Verlag, pp. 285, Berlin.

Crowther, J., 1998: New methodologies for investigating rillenkarren cross-sections: a case study at Lluc, Mallorca.- Earth Surface Processes and Landforms, 23, 333-344.

Di Stefano, P. \& A. Mindszenty, 2000: Fe-Mn-encrusted "Kamenitza" and associated features in the Jurassic of Monte Kumeta (Sicily): subaerial and/or submarine dissolution (?).-- Sedimentary Geology, 132, 37-68.

Doğan, U. \& S. Özel, 2005: Gypsum karst and its evolution east of Hafik (Sivas, Turkey).- Geomorphology, 71, 373-388.

Eren, M., 2007: Genesis of tepees in the Quaternary hardpan calcretes, Mersin, S Turkey.- Carbonates and Evaporites, 22, 2, 123-134.

Eren, M., Kadir, S., Hatipoglu, Z. \& M. Gul, 2004: Caliche development in Mersin area.- TUBITAK Project No.102Y036, Mersin, pp. 136 (in Turkish with English abstract).

Eren, M., Kadir, S., Hatipoglu, Z. \& M. Gul, 2008: Quaternary calcrete development in the Mersin area, southern Turkey.- Turkish Journal of Earth Sciences, 17, 763-784.

Esteban, M. \& C.F. Klappa, 1983: Subaerial exposure environment- In: Scholle, P.A., Bebout, D.G. \& C.H. Moore (eds.) Carbonate Depositional Environments. American Association of Petroleum Geologists Memoir 33, pp. 1-54, Tulsa.

Evans, J.E. \& J.M. Reed, 2007: Integrated loessite-paleokarst depositional system, early Pennsylvanian Molas Formation, Paradox Basin, southwestern Colorado, USA.- Sedimentary Geology, 195, 161-181.

Fiol, L.I., Fornos, J.J. \& A. Gines, 1996: Effects of biokarstic processes on the development of solutional rillenkarren in limestone rocks.- Earth Surface Processes and Landforms, 21, 447-452.

Ford, D.C. \& P.W. Williams, 1989: Karst geomorphology and hydrology.- Academic Division of Unwin Hyman Ltd, pp. 601, London.
Goudie, A.S., 1973: Duricrusts in Tropical Landscapes.Clarendon Press, pp. 174, Oxford.

Harrison, R.S., 1977: Caliche profiles: indicators of nearsurface subaerial diagenesis, Barbados, West Indies.- Bulletin of Canadian Petroleum Geology, 25, 1, 123-173.

James, N.P. \& P.W. Choquette, 1984: Diagenesis 9. Limestones- The meteoric diagenetic environment.Geoscience Canada, 11, 4, 161-194.

Jennings, J.N. \& M.M. Sweeting, 1961: Caliche pseudoanticlines in the Fitzroy Basin, western Australia.American Journal of Science, 259, 635-639.

Kadir, S. \& M. Eren, 2008: The occurrence and genesis of clay minerals associated with Quaternary caliches in the Mersin area, southern Turkey.- Clays and Clay Minerals, 56, 2, 244-258.

Kendall, C.G.St.C. \& J. Warren, 1987: A review of the origin and setting of tepees and their associated fabrics.- Sedimentology, 34, 1007-1027.

Lepirica, A., 2008: Geomorphological chracteristics of the massif Prenj.- Acta Carsologica, 37, 2-3, 307329.

Lipar, M., 2009: Pinnacle syngenetic karst in Nambung National Park, Western Australia.- Acta Carsologica, 38, 1, 41-50.

Miller, D.J. \& S.F. Mitchell, 2003: Palaeokarstic surfaces in the upper Cretaceous limestones of central Jamaica.- Cretaceous Research, 24, 119-128.

Molina, J.M., Ruiz-Ortiz, P.A. \& J.A. Vera, 1999: A review of polyphase karstification in extensional tectonic regimes: Jurassic and Cretaceous examples, Betic Cordillera, southern Spain.- Sedimentary Geology, 129, 71-84.

Öztaş, T., 1992: Karst and karstification features of the surrounding area of Boğsak karst spring (MersinTaşucu).- Jeoloji Mühendisliği Dergisi, 41, 118-130 (in Turkish with English abstract).

Price, A.W., 1925: Caliche and pseudo-anticlines.- American Association of Petroleum Geologists Bulletin, 9, 1009-1017.

Siesser, W.G., 1973: Diagenetically formed ooids and intraclasts in South African calcretes.- Sedimentology, 20, 539-551.

Sweeting, M.M., 1973: Karst landforms.- Columbia University Press, pp. 362, New York. 
Vanstone, S.D., 1996: The influence of climatic change on exposure surface development: a case study from the Late Dinantian of England and Wales- In: Strogen, P., Somerville, I.D. \& G.L.L. Jones (eds.) Recent Advances in Lower Carboniferous Geology. Geological Society Special Publication No. 107, 281-301.

Vanstone, S.D., 1998: Late Dinantian palaeokarst of England and Wales: implications for exposure surface development.- Sedimentology, 45, 19-37.

Walkden, G.M., 1974: Palaeokarstic surfaces in upper Visean (Carboniferous) limetones of the Derbyshire, Block, England.- Journal of Sedimentary Petrology, 44, 4, 1232-1247.

Watts, N.L., 1977: Pseudo-anticlines and other structures in some calcretes of Botswana and South Africa.Earth Surface Processes, 2, 63-74.

Watts, N.L., 1980: Quaternary pedogenic calcretes from the Kalahari (southern Africa): mineralogy, genesis and diagenesis.- Sedimentology, 27, 661-686.

White, W.B., 1988: Geomorphology and hydrology of karst terrains.- Oxford University Press, pp. 464, Oxford.
Wray, R.A.L., 1997: A global review of solutional weathering forms on quartz sandstones.- Earth Science Reviews, 42, 137-160.

Wright, V.P., 1982: The recognition and interpretation of paleokarsts: two examples from the lower Carboniferous of South Wales.- Journal of Sedimentary Petrology, 52, 1, 83-94.

Wright, V.P., 1988: Palaeokarsts and palaeosols as indicators of palaeoclimate and porosity evolution: a case study from the Carboniferous of South Wales.- In: James, N.P. \& P.W. Choqutte (eds.) Palaeokarst. Springer-Verlag, pp. 329-3491, New York.

Wright, V.P. \& M.E. Tucker, 1991: Calcretes.- Blackwell Scientific Publications, pp. 351, Oxford.

Yılmaz, I.Ö. \& D. Altıner, 2006: Cyclic palaeokarst surfaces in Aptian peritidal carbonate successions (Taurides, southwest Turkey): internal structure and response to mid-Aptian sea-level fall.- Cretaceous Research, 27, 814-827. 